\title{
Review: Study of a French City
}

Author(s): R. N. R. B.

Review by: R. N. R. B.

Source: The Geographical Journal, Vol. 42, No. 6 (Dec., 1913), p. 555

Published by: geographicalj

Stable URL: http://www.jstor.org/stable/1778515

Accessed: 20-06-2016 20:59 UTC

Your use of the JSTOR archive indicates your acceptance of the Terms \& Conditions of Use, available at

http://about.jstor.org/terms

JSTOR is a not-for-profit service that helps scholars, researchers, and students discover, use, and build upon a wide range of content in a trusted digital archive. We use information technology and tools to increase productivity and facilitate new forms of scholarship. For more information about JSTOR, please contact support@jstor.org.

The Royal Geographical Society (with the Institute of British Geographers), Wiley are collaborating with JSTOR to digitize, preserve and extend access to The Geographical Journal 
way as a fishing line will under the strain of a heavy fish, and if it is an authenticated fact, as it appears to be, that whales have fouled and parted cables while the latter have been in the process of being laid, there is no reason for questioning the idea that the intrusion of a cannon-ball into the privacy of deep-water life might occasionally arouse the anger of some great fish, which would attack on sight and probably cause the loss of the shot and some hundreds of fathoms of wire. On the authority of a recent article in the Field, it seems that the salmon is suspected of indulging in outbursts of temper over mere trifles, and a deep-sea monster is not likely to be more amiable.

It may be remembered by some that the cable steamer John Pender (the original boat of that name) had an experience on the above lines about eighteen years ago when sounding on the West African coast, and the paragraph that appeared in the daily papers was confirmed verbally by her officers to the effect that the wire was running out freely until the drum stopped owing to the shot striking bottom apparently, but the strain immediately came on again, the wire sheering about and finally breaking under heavy strain. It is conceivable that the foregoing phenomenon might be caused by the subsidence of the side of a steep gully (such as are traceable, even many miles seaward, of the mouths of rivers like the Congo), the irresistible rush of such an avalanche of mud snapping even heavily armoured cables. To digress slightly, a ship has been known to anchor unwittingly on the edge of one of these gullys in some 6 fathoms of water, and during the night the straining of the ship on her cable in a strong current has been sufficient to start the mud-slide, and away the vessel went drifting down-river with no bottom at 40 fathoms.

\section{REVIEWS.}

\section{EUROPE.}

\section{Study of a French City}

'Rouen : Etude d'une agglomération urbaine.' Par J. Levainville. Paris : Armand Colin. 1913. Pp. 418. Maps, Illustrations and Diagrams. $7 \mathrm{fr} .50$.

Tirs book, by the author of the valuable study of the human geography of Morvan published a few years ago, is another of the important geographical researches which we look for from time to time from the French school of geographers. It is the sort of work which might well be used to convince the sceptical that there is such a thing as research in geography, apart from research in the sciences from which the geographer borrows many of his facts. It suggests also the enormous amount of detailed work that is awaiting geographers to undertake it. The volume is divided into three parts. The geographical position and the site of Rouen are first studied, this entailing a consideration of physical factors. Then the activities of Rouen are noticed at considerable length and interpreted, while lastly come a consideration of the town itself and its evolution and the movements of its population. There is a long and seemingly exhaustive bibliography. A large-scale folding-map (Service Géographique de l'Armée) is added, as well as a plan of Rouen, but, as usual in French works, there is no index-a great inconvenience.

R. N. R. B. 